Article

\title{
Ecologically Embedded Design in Manufacturing: Legitimation within Circular Economy
}

\author{
Hana Trollman ${ }^{1, * \mathbb{C}}$, James Colwill ${ }^{1}$ and Alan Brejnholt ${ }^{2}$ (D) \\ 1 Wolfson School of Mechanical, Electrical and Manufacturing Engineering, Loughborough University, \\ Leicestershire LE11 3TU, UK; j.a.colwill@lboro.ac.uk \\ 2 Institute for International Management, Loughborough University London, London E15 2GZ, UK; \\ a.brejnholt@lboro.ac.uk \\ * Correspondence: h.trollman2@lboro.ac.uk
}

Received: 24 April 2020; Accepted: 20 May 2020; Published: 22 May 2020

\begin{abstract}
Circular economy has gained momentum since the 1970s as a regenerative alternative to the traditional linear economy. However, as the circular economy has gone mainstream, circularity claims have become fragmented and remote, consisting of indirect contributions, such as the life extension of other products and the use of waste as feedstock, without addressing the actual cause of waste. The present study aims to identify the strategic motivations of manufacturers participating in the circular economy and the corresponding relationship to ecological embeddedness. This paper explores the circular economy in manufacturing through existing products on the market and their relationship to eco-design by considering the product, packaging, and its production. Legitimacy is found to be a decisive factor in whether the type of circular economy strategy manufacturers adopt yields ecological benefits. The results from the case study of products clearly indicate the superiority of ecological embeddedness, as a form of circularity supporting strong sustainability. Finally, a novel template is proposed to support the implementation of ecological embeddedness in manufacturing.
\end{abstract}

Keywords: circular economy; ecological embeddedness; design; legitimacy; sustainability; manufacturing; ecocentric

\section{Introduction}

The concept of circular economy (CE) has been proposed to replace the unsustainable take-make-dispose approach of linear manufacturing [1]. The sensu stricto definition of CE [2] concerns the technological cycle of resources mainly through the slowing and closing of resource loops, and is the subject of extensive research [3,4].

However, the broader focus of the sensu latu definition [5], which defines CE as "an economic model wherein planning, resourcing, procurement, production and reprocessing are designed and managed, as both process and output, to maximize ecosystem functioning and human well-being", is poorly understood as ecocentric business strategies are still in the theoretical stage of development [6].

Usage and waste by the manufacturing sector is expected to increase ten-fold over the next fifty years [7]. The sustainability of future manufacturing will depend on the sustainability of its environment $[8,9]$. Consequently, it is important to understand how the manufacturing sector can be engaged in the broader definition of CE proportional to its impacts.

CE research has mainly focused on macro and industrial levels but less on the circular capabilities of manufacturing [10]. An effective circular manufacturing system should consider different lifecycle scenarios representing how products, modules, parts, and materials are circulated to reduce resource consumption and environmental load [11]. Circular manufacturing lies at the intersection of research 
areas, such as sustainable product design, sustainable supply chains, and reverse logistics, but there is scarce literature on how these concepts relate to company transition to circularity [12].

The ecological embeddedness of manufacturing, or a locally responsive strategy that is sensitive to local ecosystems, has been called for in literature to support strong sustainability [13]. Unlike CE or sustainability in terms of the Triple Bottom Line (TBL), which are predominantly driven by economic considerations [14,15], ecological embeddedness is ecocentric. Locating manufacturer strategies along the continuum of CE practices whilst differentiating those that are ecologically embedded is of particular interest in revealing the benefits of adoption and informing policymaking for consumer and environmental protection. Ecological embeddedness has not been previously investigated in the context of manufacturing.

The present study explores the relationships between CE and ecological embeddedness for manufacturing with the objective of better understanding how and why manufacturers participate in the $\mathrm{CE}$ with respect to design decisions. This study therefore sought to understand the strategic nature of design decisions in CE. Case studies of products sold in the United Kingdom (UK) are investigated to make a novel contribution in identifying what distinguishes CE design strategy from that of ecological embeddedness. Manufacturers are found to engage with circularity for differentiation, cost saving, and/or legitimacy reasons. The manufacturer or consumer benefits are either addressed directly through the redesign of the product, process, or packaging or as part of public relations, with no impactful change on business as usual.

\section{Literature Review}

The literature review provides a brief overview and comparison of the business-level understanding of $\mathrm{CE}$ and ecological embeddedness.

\subsection{What Are the Benefits of CE Strategies?}

The slowing, closing, and narrowing of loops terminology is used to distinguish CE models from linear models [2]. The strategy of slowing loops is achieved through the design of longer-lasting products and extending product life through maintenance and repair. Consumers benefit directly from such a strategy, but the effect on the manufacturer is to slow turnover, which may be offset through increased price. The environmental impact is only delayed, and if very inefficient products that cannot be up-graded remain in circulation longer, there may be questionable environmental benefit.

On the other hand, narrowing loops is a form of resource efficiency which benefits the manufacturer directly but does not affect the speed of the flow of products or involve any service loops. The cumulative environmental benefit is therefore uncertain.

Closing loops means that recycling is used between post-use and production to result in a circular flow of resources. Consequently, fewer virgin resources are mined or extracted from the environment. Assuming that extracting virgin resources is more environmentally damaging than recycling and that the cost of recycling is at least competitive in price and quality to encourage the purchase of recycled resources, the environment benefits [16]. The manufacturer may also benefit if critical materials are maintained in their supply chain, but this is a strategic advantage that is not currently being realized [17].

The above discussion is applicable to products. No universal methodology currently exists that would enable the complex assessment of packaging in relation to particular products in the context of the CE [18].

\subsection{How Have Researchers Viewed CE in a Business Context?}

There are two main categories of CE business strategies: slowing resource loops and closing loops [2]. However, a recent review identified that only $39.82 \%$ of research papers could be categorized based on these proposed strategies, and only $16 \%$ explored two or more business models at the same time [19]. Few studies investigate how firms may capture CE principles in their business practices $[3,20]$. 
CE initiatives addressing consumers are largely missing, even though they are considered critical for the CE transition [21].

A product circularity assessment methodology has been proposed based on four principles: use less, absorb circularities, generate circularities, and use renewable resources [22]. However, although energy, materials, and auxiliary resources are considered, the environmental impact is viewed only in relation to traditional alternatives and there is no consideration of the open-loop recycling of waste and byproduct treatment.

Corporate strategies need to focus on both product design and business model innovation. Publications on circular product design have been mainly conceptual in nature [3]. Although the design skills needed to support closed loops have been investigated [23], eco-design and internal environmental management practices do not have a high level of implementation and indicate a lack of consideration of design for product reuse or recycling [24].

An investigation of various contributions to the concept of $\mathrm{CE}$ arrived at the following definition: "a regenerative system in which resource input and waste, emission, and energy leakage are minimized by slowing, closing, and narrowing material and energy loops. This can be achieved through long-lasting design, maintenance, repair, reuse, remanufacturing, refurbishing, and recycling" [14]. Consequently, the $\mathrm{CE}$ is focused on resources as opposed to the preservation of biophysical systems.

In the next sections, ecological embeddedness will be presented to enable a comparison with CE.

\subsection{What Is Ecological Embeddedness?}

Ecological embeddedness has been introduced as the extent to which a manager is on the land and learns from the land in an experiential way [25]. The associated dimensions of ecological embeddedness are personal identification with the land, adherence to ecological beliefs (with ecological reciprocity, ecological respect, and ecological caretaking as subdimensions), gathering ecological information, and being physically located in the ecosystem. This description of ecological embeddedness has certain parallels in manufacturing with environmental stewardship [26-28].

In the context of on-farm food production, it has been proposed that ecological embeddedness should be viewed as the ways in which ongoing ecological relations (i.e., relationships between economic actors and the underlying ecology of production) influence economic activity such that a benefit is produced for both [29].

This has been extended to examine how stakeholders understand, realize, utilize, and negotiate the ecological dimension of food production [30]. Three different forms of ecological embeddedness are found to depend on how the ecological dimensions of production are linked with environmental protection issues:

- Ecological practices are presented as being environmentally-friendly.

- Ecological practices are presented through their impact on product quality (not environmental protection).

- Ecological "dis-embeddedness" results due to technical and/or market constraints.

The introduction of ecological embeddedness is not restricted to food production, but rather is an alternative approach to management [25]. Although food production requires special considerations such as the need for fresh perishable ingredients, health risks associated with inappropriate production environment, and stringent storage and distributions requirements, together with a relatively short post-production shelf-life [31], sustainability remains dependent on the production process [32] and product [33]. Therefore, an association may be made with manufacturing by linking environmentally-friendly practices with the design of the production system and the impact on product quality through eco-design. 


\subsection{Comparison of CE and Ecological Embeddedness Strategies}

In Table 1, a summary of benefits for the strategies of CE and ecological embeddedness is presented based on Sections 2.1-2.3. Ecological embeddedness concerns the relations between economic actors (producer and consumer-in this case, more specifically the manufacturer and consumer) and the environment (the underlying ecology of production). Other beneficiaries may be more appropriately considered under forms of social embeddedness.

If manufacturers regard CE strategies as mutually exclusive or that adopting one ticks the box of participation in the $\mathrm{CE}$, there may be no environmental benefit.

Ecological embeddedness means that both the economic actors (manufacturer and consumer) and the environment benefit. The mechanism for achieving this may involve the co-design of the product and production system [34], or the continuous improvement of an existing system.

Corporate Social Responsibility strategies, arguably an umbrella for both CE and ecological embeddedness, have been related to differential advantage and/or legitimation effects $[35,36]$. This research takes a strategic approach to organizational legitimacy [37]. Legitimacy may be a manufacturer benefit of participation in the $\mathrm{CE}$ and/or the result of the manufacturer being ecologically embedded. This research aims to clarify if and how such legitimacy also benefits the economic actors (manufacturer and consumer) and the environment.

Table 1. Strategies and beneficiaries of the circular economy and ecological embeddedness.

\begin{tabular}{|c|c|c|c|c|c|}
\hline & & & \multicolumn{3}{|c|}{ Beneficiary } \\
\hline & & & Manufacturer & Consumer & Environment \\
\hline \multirow{5}{*}{ Strategy } & \multirow{3}{*}{$\begin{array}{c}\text { Circular } \\
\text { Economy }(\mathrm{CE})\end{array}$} & closing loop & - & - & $\sqrt{ }$ \\
\hline & & narrowing loop & $\sqrt{ }$ & - & - \\
\hline & & slowing loop & - & $\sqrt{ }$ & - \\
\hline & \multirow{2}{*}{$\begin{array}{c}\text { Ecological } \\
\text { Embeddedness }\end{array}$} & eco-design of production & $\sqrt{ }$ & - & $\sqrt{ }$ \\
\hline & & eco-design of product quality & - & $\sqrt{ }$ & $\sqrt{ }$ \\
\hline
\end{tabular}

\subsection{Conceptual Framework}

CE loops [2] and the different forms of ecological embeddedness [30] form the core of the conceptual framework. The lack of research involving more than one CE business model [19] would suggest manufacturers predominantly implement a single CE loop as part of their strategy. The literature also suggests that ecological embeddedness may be applied to manufacturing in terms of the categorization of ecological practices as environmentally friendly or by the impact on product quality, as explained in Section 2.3. Even though both CE loops and ecological embeddedness through the design of products, processes, and packaging are strategically related, the nature of the relationship is unclear. Table 1 suggests that narrowing loops are related to the eco-design of production, slowing loops are related to the eco-design of product quality, and closing loops may involve both. This research aims to determine the nature of these relationships.

\section{Methods}

Having established the ecological shortcomings of CE strategies from the literature review, the next step is to identify what CE strategies manufacturers are adopting; why these strategies are being adopted; and what the implications are for the design of the product, process, and packaging.

The methodology employed was that of a qualitative comparative multiple case study for producing analytical generalizations [38]. This methodology has been used to address sustainability issues of firms [39]. Case studies are appropriate when there are clearly identifiable cases with boundaries and the research seeks to compare these cases [40]. Maximum variation sampling was used as an exploratory sampling strategy to identify the typical cases. Category zooming [41] focused on 
particular single aspects of the qualitative data corresponding to the theory of CE loops and ecological embeddedness presented in the previous section. The data were approached conventionally in three stages: organizing, reducing, and comparing [42], as shown in the overview of methodology in Figure 1.

\begin{tabular}{|c|c|c|}
\hline \multirow{2}{*}{\multicolumn{3}{|c|}{$\begin{array}{l}\text { Literature review of CE theory and ecological embeddedness } \\
\text { Critical reflection on CE loops }\end{array}$}} \\
\hline & & \\
\hline \multirow[t]{4}{*}{ Data collection } & \multicolumn{2}{|c|}{ Case identification } \\
\hline & \multicolumn{2}{|c|}{ Maximum variation sampling } \\
\hline & \multicolumn{2}{|c|}{ Typical case selection } \\
\hline & \multicolumn{2}{|c|}{$\begin{array}{l}\text { Observation and participant observation } \\
\text { of products, retailer websites and } \\
\text { manufacturer websites, document } \\
\text { collection and photography }\end{array}$} \\
\hline Data organization & $\begin{array}{l}\text { Category zooming on CE loops } \\
\text { (slowing, closing, narrowing) }\end{array}$ & $\begin{array}{l}\text { Category zooming on ecological embeddedness } \\
\text { (environmentally-friendly, product quality) }\end{array}$ \\
\hline \multirow[t]{2}{*}{ Data reduction } & \multicolumn{2}{|c|}{ Identification of CE benefits } \\
\hline & \multicolumn{2}{|c|}{$\begin{array}{l}\text { Coding of CE benefits } \\
\text { (manufacturer, consumer) }\end{array}$} \\
\hline Data comparison & \multicolumn{2}{|c|}{ Domain analysis and comparison with theory } \\
\hline
\end{tabular}

Figure 1. Overview of methods.

A broad range of products for the case study were identified in an unbiased manner based on manufacturer self-identification as selling sustainable, green, and/or circular products in the UK in the period of August-November 2019. The products were located through the Sainsbury's online shopping website feature for the selection of eco-friendly products, the Ellen MacArthur Foundation website, and Circular Economy Club member organizations in the UK.

The data collection process consisted of product investigation at physical retailers and/or online retailers and the concurrent examination of information on manufacturer websites. The physical retailers that were visited were the Toyota dealership (Loughborough), IKEA (Nottingham), white goods retailers (Loughborough and Leicester), hardware retailers (Loughborough), and grocery stores (Loughborough). The solely online retailers' websites that were visited were those of Greenscents, Kinn Living, e-cloth, MUD jeans, Veja Shoes, and Fairphone. The solely manufacturer websites that were visited were those of TATA steel and Finning Caterpillar.

This method of data collection was selected as marketing is the way that manufacturers establish relationships with the general public, including potential consumers. If information about $\mathrm{CE}$ or ecological embeddedness is not being communicated, it is irrelevant to the purchasing decision and does not form the basis of any ecological relationship.

A data analysis of the information from these sources was first used to determine which CE loops were present for the product, its packaging, and the process used to manufacture it based on the slowing, closing, and narrowing loops defined in the literature review above. Biological loops, the use of byproducts, and reducing transport are rarely considered in CE literature and were categorized in this research as closing loops for consistency with their definition.

In the next step of the data analysis, the predominant form of ecological embeddedness was identified based on the marketing material collected and whether it highlighted the ecological practices of the manufacturer as being environmentally friendly or if the focus was on the effect of ecological practices on product quality.

Finally, the benefits to the economic actors arising from the ecological design features of the product, packaging, or manufacturing process were noted. Benefits were coded as cost-saving for the manufacturer; money-saving for the consumer; legitimacy; customer loyalty; and/or consumer health, which includes safety. Benefits internal to the manufacturer, such as improved employee health and safety and reduced risk for shareholders, were not considered for the reasons of focusing on external relationships with the environment (natural and business) and that such benefits are 
rarely communicated through the sources investigated. Both CE and ecologically embeddedness are concerned with external relationships, whereas internal aspects might be more appropriately considered under embedded sustainability.

The UK motivates investigations related to CE for two main reasons: (1) the UK developed the first practical framework and guidance for organizations to implement circular economy principles in BS 8001: 2017 [43], indicating that the UK is adopting a progressive bottom-up approach to CE (this can be contrasted with China's top-down approach); and (2) the UK is still part of the European Union (EU) and so is bound by environmental regulations set at the EU level. Both reasons have implications for organizational legitimacy.

\section{Results}

A total of 27 products were included in the initial cases, as they were identified by the manufacturer as being sustainable, green, and/or circular. A representative product was selected for situations in which a manufacturer had more than one product line that fell into these categories. These were reduced to 17 illustrative examples to eliminate duplications in products and loops. Table 2 identifies the products and manufacturers under consideration, their claim to circularity, the form of ecological embeddedness based on [30] as described in Section 2.3, and the benefits derived from CE. Biological loops, the use of byproducts, and reducing transport are considered to close loops.

Table 2. Case products, circularity, ecological embeddedness, and benefits derived from the circular economy (CE). " $\mathrm{X}$ " indicates that no circular economy loop information is presented by the manufacturer.

\begin{tabular}{|c|c|c|c|}
\hline Product/Manufacturer & $\begin{array}{l}\text { Circular Economy } \\
\text { Loops }\end{array}$ & $\begin{array}{l}\text { Form of Ecological } \\
\text { Embeddedness }\end{array}$ & $\begin{array}{l}\text { Benefits Derived from CE } \\
\text { (Manufacturer/Consumer) }\end{array}$ \\
\hline \multirow{3}{*}{$\begin{array}{c}\text { Sugar (Silverspoon, } 2 \text { kg), } \\
\text { AB Sugar }\end{array}$} & $\begin{array}{l}\text { process-narrowing, } \\
\text { closing }\end{array}$ & \multirow{3}{*}{ environmentally-friendly } & \multirow{3}{*}{$\begin{array}{c}\text { manufacturer (cost savings } \\
\text { and legitimacy) }\end{array}$} \\
\hline & product-closing & & \\
\hline & packaging-closing & & \\
\hline \multirow{3}{*}{$\begin{array}{c}\text { batteries (8 pack, AA), } \\
\text { Duracell }\end{array}$} & process-X & \multirow{3}{*}{ product quality } & \multirow{3}{*}{$\begin{array}{c}\text { consumer (money savings: } \\
\text { cascading POWERCHECK, } \\
\text { long-lasting) }\end{array}$} \\
\hline & product_-slowing & & \\
\hline & packaging_closing & & \\
\hline \multirow{3}{*}{$\begin{array}{l}\text { toilet cleaner (pine \& mint } \\
750 \mathrm{~mL} \text { ), Ecover }\end{array}$} & $\begin{array}{l}\text { process-narrowing, } \\
\text { closing }\end{array}$ & \multirow{3}{*}{ environmentally-friendly } & \multirow{3}{*}{$\begin{array}{c}\text { manufacturer (cost savings, } \\
\text { legitimacy, and customer } \\
\text { loyalty: refills) }\end{array}$} \\
\hline & product-closing & & \\
\hline & $\begin{array}{l}\text { packaging-slowing, } \\
\text { closing }\end{array}$ & & \\
\hline \multirow{3}{*}{$\begin{array}{l}\text { washing up liquid } \\
(400 \mathrm{~mL}), \text { Greenscents }\end{array}$} & process $-X$ & \multirow{3}{*}{ environmentally-friendly } & \multirow{3}{*}{$\begin{array}{c}\text { manufacturer (legitimacy } \\
\text { and customer loyalty: refills) }\end{array}$} \\
\hline & product-closing & & \\
\hline & $\begin{array}{l}\text { packaging-slowing, } \\
\text { closing }\end{array}$ & & \\
\hline \multirow{3}{*}{$\begin{array}{l}\text { organic body wash } \\
(200 \mathrm{~mL}), \text { Kinn Living }\end{array}$} & process-X & \multirow{3}{*}{ product quality } & \multirow{3}{*}{$\begin{array}{l}\text { consumer (health: natural } \\
\text { and organic) }\end{array}$} \\
\hline & product-closing & & \\
\hline & packaging-closing & & \\
\hline \multirow{3}{*}{$\begin{array}{l}\text { mop (Deep Clean Mop), } \\
\text { e-cloth }\end{array}$} & process $-X$ & \multirow{3}{*}{ product quality } & \multirow{3}{*}{$\begin{array}{c}\text { consumer (money savings } \\
\text { on chemicals, durability, } \\
\text { health) }\end{array}$} \\
\hline & $\begin{array}{l}\text { product-slowing, } \\
\text { closing }\end{array}$ & & \\
\hline & packaging-X & & \\
\hline \multirow{3}{*}{$\begin{array}{c}\text { Hardtack (beer in can), } \\
\text { Jaw Brew }\end{array}$} & $\begin{array}{l}\text { process-narrowing, } \\
\text { closing }\end{array}$ & \multirow{3}{*}{ environmentally-friendly } & \multirow{3}{*}{$\begin{array}{c}\text { manufacturer (cost savings } \\
\text { and legitimacy) }\end{array}$} \\
\hline & product-closing & & \\
\hline & packaging-closing & & \\
\hline
\end{tabular}


Table 2. Cont.

\begin{tabular}{|c|c|c|c|}
\hline Product/Manufacturer & $\begin{array}{l}\text { Circular Economy } \\
\text { Loops }\end{array}$ & $\begin{array}{l}\text { Form of Ecological } \\
\text { Embeddedness }\end{array}$ & $\begin{array}{l}\text { Benefits Derived from CE } \\
\text { (Manufacturer/Consumer) }\end{array}$ \\
\hline \multirow{3}{*}{$\begin{array}{l}\text { hot-rolled steel for } \\
\text { automotive industry, } \\
\text { TaTa Steel }\end{array}$} & $\begin{array}{l}\text { process-narrowing, } \\
\text { closing }\end{array}$ & \multirow{3}{*}{ environmentally-friendly } & \multirow{3}{*}{$\begin{array}{c}\text { manufacturer (cost savings } \\
\text { and legitimacy) }\end{array}$} \\
\hline & product-closing & & \\
\hline & packaging-closing & & \\
\hline \multirow{3}{*}{ jeans, MUD Jeans } & $\begin{array}{l}\text { process-narrowing, } \\
\text { closing }\end{array}$ & \multirow{3}{*}{ environmentally-friendly } & \multirow{3}{*}{$\begin{array}{c}\text { manufacturer (cost savings, } \\
\text { legitimacy, customer loyalty: } \\
\text { rent a jeans) }\end{array}$} \\
\hline & product-closing & & \\
\hline & packaging-slowing & & \\
\hline \multirow{3}{*}{ shoes, Veja Shoes } & process-closing & \multirow{3}{*}{ environmentally-friendly } & \multirow{3}{*}{ manufacturer (legitimacy) } \\
\hline & $\begin{array}{c}\text { product-closing (some } \\
\text { shoes) }\end{array}$ & & \\
\hline & packaging-X & & \\
\hline \multirow{3}{*}{ mobile phone, Fairphone } & $\begin{array}{l}\text { process-narrowing, } \\
\text { closing }\end{array}$ & \multirow{3}{*}{ product quality } & \multirow{3}{*}{$\begin{array}{c}\text { consumer (money savings: } \\
\text { longevity, easy repair, } \\
\text { modular upgrades) }\end{array}$} \\
\hline & $\begin{array}{l}\text { product-slowing, } \\
\text { closing }\end{array}$ & & \\
\hline & packaging $-X$ & & \\
\hline \multirow{3}{*}{$\begin{array}{l}\text { washing machine (Eco } \\
7 \mathrm{~kg} \text { ), Miele }\end{array}$} & process-X & \multirow{3}{*}{ product quality } & \multirow{3}{*}{$\begin{array}{l}\text { consumer (money savings: } \\
\text { built to last, energy and } \\
\text { water consumption) }\end{array}$} \\
\hline & $\begin{array}{l}\text { product-slowing, } \\
\text { closing }\end{array}$ & & \\
\hline & packaging $-X$ & & \\
\hline \multirow{3}{*}{$\begin{array}{l}\text { American fridge freezer } \\
\text { (LSR100), LG }\end{array}$} & process-X & \multirow{3}{*}{ product quality } & \multirow{3}{*}{$\begin{array}{c}\text { consumer (money savings: } \\
\text { Instaview door for less } \\
\text { energy use) }\end{array}$} \\
\hline & product-closing & & \\
\hline & packaging-X & & \\
\hline \multirow{3}{*}{$\begin{array}{l}\text { Insulation (6 pack, } \\
1200 \mathrm{~mm} \times 400 \mathrm{~mm} \times \\
10 \mathrm{~mm} \text { ), Rockwool }\end{array}$} & process-closing & \multirow{3}{*}{ product quality } & \multirow{3}{*}{$\begin{array}{l}\text { consumer (money savings: } \\
\text { energy performance; health: } \\
\text { fire safety) }\end{array}$} \\
\hline & product-closing & & \\
\hline & packaging-X & & \\
\hline \multirow{3}{*}{$\begin{array}{l}\text { kitchen furniture } \\
\text { (Kungsbacka), IKEA }\end{array}$} & process-closing & \multirow{3}{*}{ environmentally-friendly } & \multirow{3}{*}{$\begin{array}{l}\text { manufacturer (legitimacy, } \\
\text { product closing loop for } \\
\text { loyalty is still theoretical) }\end{array}$} \\
\hline & product-closing & & \\
\hline & packaging-closing & & \\
\hline \multirow{3}{*}{ hybrid car (Camry), Toyota } & process $-X$ & \multirow{3}{*}{ product quality } & \multirow{3}{*}{$\begin{array}{l}\text { consumer (money savings: } \\
\text { fuel economy, hybrid brake } \\
\text { pads last longer, lower } \\
\text { emissions for road tax } \\
\text { savings) }\end{array}$} \\
\hline & $\begin{array}{l}\text { product-slowing, } \\
\text { closing }\end{array}$ & & \\
\hline & packaging $-X$ & & \\
\hline \multirow{3}{*}{$\begin{array}{l}\text { landfill compactor (Cat } 81 \\
6 \mathrm{~K}-\text { one of Cat's most } \\
\text { rebuilt products), Finning } \\
\text { Caterpillar }\end{array}$} & $\begin{array}{l}\text { process-narrowing, } \\
\text { closing }\end{array}$ & \multirow{3}{*}{ product quality } & \multirow{3}{*}{$\begin{array}{l}\text { consumer (money savings: } \\
\text { designed to last and } \\
\text { rebuild/remanufacture) }\end{array}$} \\
\hline & $\begin{array}{l}\text { product-slowing, } \\
\text { closing }\end{array}$ & & \\
\hline & packaging-X & & \\
\hline
\end{tabular}

\section{Discussion}

\subsection{Analysis and Template Development}

The strength of the approach taken in this study is that the ecological impacts of actual design decisions are interrogated. In Table 2, CE loops address the question of how manufacturers participate in CE. Benefits are considered as opposed to value. Benefits are the result of design features that may or may not lead to the value proposition being realized-e.g., Duracell batteries may be purchased 
for the POWERCHECK feature, but the customer may never use it; the mobile phone may never be repaired or upgraded.

Many consumer goods address a need but do not consider that there may be more ecological ways of satisfying needs-e.g., second-hand clothing and public transport. Similarly, adopting a broad range of circularity loops, as in the case of beer brewed with surplus bread, does not address the cause of waste. Cleaning products and household appliances extend the life of other products, but there may be less expensive and more environmentally-friendly alternatives.

The CE loop strategy adopted by the manufacturer is shown to obscure the ecological benefit unlike the form of ecological embeddedness, wherein product quality in the cases corresponds to consumer benefits, and highlighting being environmentally friendly corresponds to manufacturer benefits. Product quality is focused on differentiation as a strategy, whereas being environmentally friendly is predominantly a legitimacy strategy. This answers the question of why manufacturers adopt CE.

The related design decisions are the eco-design of processes for legitimacy and potential cost savings for the manufacturer. The eco-design of the product is for legitimacy, money savings for the consumer, perceived health benefits for the consumer and/or for customer loyalty if there is a take-back scheme, which may involve the rental of the product or sale with cashback as motivation for return. The eco-design of packaging is for legitimacy if it is part of a closing loop (recyclable) or narrowing loop (reusable), for cost savings if it is reusable, and for customer loyalty if the packaging can be refilled by the consumer.

The range of case products exhibiting some form of circularity is from near monopoly through to oligopoly and monopolistic competition. Sugar in the UK exists in a near monopoly (monopsony with respect to growers). The battery market in the UK is dominated by Duracell and Energizer, with Panasonic and JCB as other notable brands. Similarly, the automobile market share is divided among a small number of manufacturers, another example of an oligopoly. Conversely, textbook examples of monopolistic competition include clothing and shoes.

Although no particular significance is found to be attached to the market system with respect to circularity, it is reasonable to consider why manufacturers with near monopolies would bother engaging in CE. This leads to a deeper consideration of legitimacy.

In general, legitimacy is a much cheaper means of securing compliance with rules and norms than coercion [44]. Legitimacy is a relational property and is consequently relevant to ecological embeddedness with its focus on relations. Linked legitimacy may be considered a resource that is built around sustainable development projects and strategies [45].

A successful strategy of legitimation may constitute a benefit to the manufacturer in the form of a distraction from an ecological issue that is costly to address [46]. Sugar is a case in point, as the manufacture gives the appearance of a circular role model in a near monopoly market, yet concerns about human health and soil loss [47] indicate a failure in ecological embeddedness both upstream and downstream of production. An important question is to what extent consumers are evaluating manufacturers on normative standards rather than the capacity to deliver substantive ecological benefits.

Organizations can become legitimate in three ways [48]:

1. Adapting output, goals, and methods of operation to conform to prevailing definitions of legitimacy;

2. Using communication to attempt to alter the definition of legitimacy for conformity with present organizational practices, output, and values; and/or

3. Using communication to become identified with symbols, values, or institutions which have a strong base of legitimacy.

The template in Figure 2 relates eco-design to the above actions for legitimacy, differentiating ecological embeddedness as a subset of circular economy as practiced by manufacturers which does not include legitimation without design changes. 


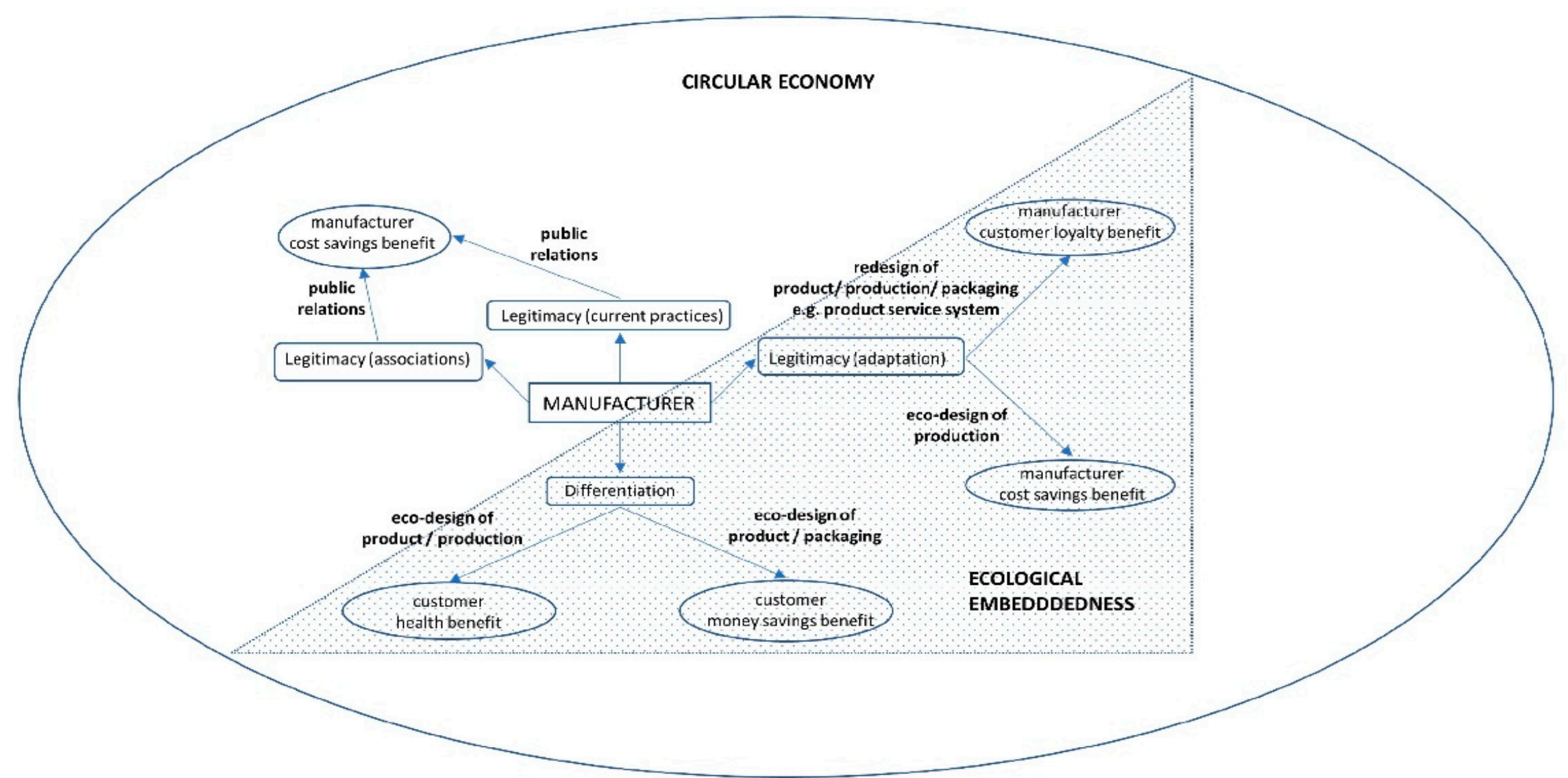

Figure 2. Template of strategic drivers for $\mathrm{CE}$ and ecological embeddedness in terms of benefits and realization. Ecological embeddedness (triangle) with related design decisions is shown as a subset of $\mathrm{CE}$ (oval). 
To satisfy the definition of ecological embeddedness, a manufacturer needs to employ both differentiation and legitimacy through adaptation to provide ecological benefits to both economic actors and the environment. This requires an integrated approach to design of product, process, and packaging.

Figure 2 is also significant for what is missing - no benefit acts as a driver for design for recycling for either the manufacturer or consumer nor design for disassembly, unless this can be linked to customer loyalty benefits for the manufacturer and/or some form of cost savings.

\subsection{Template Implementation}

In the following discussion, the case of MUD jeans is exemplified for good ecologically embedded practices across all categories of the template and contrasted with Silverspoon sugar and Kungsbacka kitchen furniture. The template is used to suggest a course of action for the manufacturer.

MUD jeans differentiates itself from competitors by offering a traditional no-frills product that is produced sustainably. The jeans are made from recycled and organic cotton without pesticides or insecticides, so the claimed customer health benefit is that the jeans are better for the skin in addition to benefiting the environment. The product is designed for recycling, with buttons and rivets of stainless steel, and the leather patch has been replaced with a printed label for monomaterial recycling. Customers who participate in leasing the jeans are part of the loyalty benefit to the manufacturer. The eco-design of production uses less water than the industry standard, creating a cost savings for the manufacturer. The packaging is reusable up to 20 times, which also creates a cost saving for the manufacturer. Both the production and packaging also benefit the environment.

Silverspoon sugar focuses on local economic benefits, with a short supply chain and sustainable production. The packaging is recyclable paper and put to use in marketing the local economic and sustainability benefits as well as recipe suggestions. However, human health and soil loss are a concern [47], and these concerns are exacerbated by increased production and consumption. The template would suggest differentiation for customer benefit. This could be accomplished by using the packaging to promote responsible consumption with reduced sugar recipes (health and money savings) and highlighting how the issue of soil loss is being addressed (consumer awareness of ecological embeddedness).

The doors of the Kungsbacka kitchen furniture of IKEA are made from a minimum of $90 \%$ recycled foil and edging from PET (polyethylene terephthalate) bottles and recycled wood. Although the recycled content of this kitchen door is noted in the IKEA guide to buying kitchens and a video of the production exists on the website under design (not kitchens), it was difficult to differentiate the product as sustainable based on the in-store visit. The shop assistant indicated the kitchen was on trend with its finish and in demand for that reason, with a new white version being introduced. Differentiation on the basis of sustainability may be considered barely established and ecological embeddedness is not supported, as the relationship with ecology is not clearly communicated to many consumers. The product can be recycled repeatedly, but UK furniture recycling/reuse is only for beds, mattresses, sofas, and appliances for a fee. There is no particular benefit to the consumer, as all METOD kitchens have a 25-year guarantee and the kitchen is priced similarly to other styles. The template would suggest that if the recycled content of the kitchen is benefiting the manufacturer through cost savings, these should be passed on to the customer, whereas if there is no manufacturer or consumer cost savings benefit and the kitchen is not part of a loyalty take-back scheme, the manufacture of the Kungsbacka kitchen is not supported under ecological embeddedness.

\subsection{Summary}

The previous discussion highlights the utility of the novel template proposed in this work. In relation to the conceptual framework, manufacturers are found to employ multiple CE loops as opposed to a single CE loop as part of their strategy, which contradicts the main focus of previous research [19]. The template mitigates the complexity of multiple CE loops. Furthermore, ecological 
embeddedness in terms of ecological practices is found to be applicable to manufacturing through the consideration of eco-design decisions. Previous literature had only considered the concept of ecological embeddedness in abstract terms or in relation to agricultural production. The nature of the relationship between ecological embeddedness and the strategic purpose of eco-design decisions for products, processes, and packaging has also been explained (Section 5.1). The template serves as a guide for how manufacturers should seek synergy in benefiting both economic actors and the environment, as illustrated in Section 5.2.

\section{Conclusions}

Insufficient attention is being directed at understanding and implementing the broader definition of circular economy in manufacturing. There is a clear problem with how manufacturers are interpreting participation in the circular economy. Based on an analysis of circular products, the circular economy strategies of slowing, narrowing, and closing loops are shown to not be applied by manufacturers in appropriate combinations nor supported by a legitimation strategy intended to have a positive environmental impact. Whereas ecological embeddedness integrating the strategies of differentiation and legitimacy through adaptation results in both economic actors (manufacturer and consumer) as well as the environment benefiting, circular economy strategies lack this overarching objective. The novel template proposed in this paper provides effective guidance to manufacturers on how to harness eco-design when participating in the circular economy through ecological embeddedness so that an actual ecological benefit results.

Author Contributions: Conceptualization, H.T. and J.C.; formal analysis, H.T. and A.B.; funding acquisition, J.C.; investigation, H.T.; methodology, H.T.; project administration, H.T.; resources, J.C.; supervision, J.C.; validation, A.B.; visualization, H.T. and J.C.; writing—original draft, H.T.; writing—review and editing, H.T., J.C., and A.B. All authors have read and agreed to the published version of the manuscript.

Funding: This publication was supported by the Engineering and Physical Sciences Research Council (grant number EP/K030957/1) and the EPSRC Centre for Innovative Manufacturing in Food. Due to the nature of the research, data is not publicly available.

Acknowledgments: The authors would also like to acknowledge the useful revisions suggested by Alok Choudhary at Loughborough University.

Conflicts of Interest: The authors declare no conflict of interest.

\section{References}

1. Ghisellini, P.; Cialani, C.; Ulgiati, S. A review on circular economy: The expected transition to a balanced interplay of environmental and economic systems. J. Clean. Prod. 2016, 114, 11-32. [CrossRef]

2. Bocken, N.; De Pauw, I.; Bakker, C.; van der Grinten, B. Product design and business model strategies for a circular economy. J. Ind. Prod. Eng. 2016, 33, 308-320. [CrossRef]

3. Lieder, M.; Rashid, A. Towards circular economy implementation: A comprehensive review in context of manufacturing industry. J. Clean. Prod. 2016, 115, 36-51. [CrossRef]

4. Lüdeke-Freund, F.; Gold, S.; Bocken, N. A review and typology of circular economy business model patterns. J. Ind. Ecol. 2018, 23, 36-61. [CrossRef]

5. Murray, A.; Skene, K.; Haynes, K. The circular economy: An interdisciplinary exploration of the concept and application in a global context. J. Bus. Ethics 2017, 140, 369-380. [CrossRef]

6. Borland, H.; Lindgreen, A.; Ambrosini, V.; Vanhamme, J. Creating theory for business strategies for sustainability and climate change. In Business Strategies for Sustainability; Borland, H., Lindgreen, A., Maon, F., Vanhamme, J., Ambrosini, V., Florencio, B., Eds.; Routledge: Abingdon, UK, 2019; pp. 65-80.

7. Rashid, A.; Asif, F.; Krajnik, P.; Nicolescu, C. Resource conservative manufacturing: An essential change in business and technology paradigm for sustainable manufacturing. J. Clean. Prod. 2013, 57, 166-177. [CrossRef]

8. Sarkis, J. Manufacturing's role in corporate environmental sustainability: Concerns for the new millennium. Int. J. Oper. Prod. Manag. 2001, 21, 666-686. [CrossRef] 
9. Florida, R. Lean and green: The move to environmentally conscious manufacturing. Calif. Manag. Rev. 1996, 39, 80-105. [CrossRef]

10. Garza-Reyes, J.; Kumar, V.; Batista, L.; Cherrafi, A.; Rocha-Lona, L. From linear to circular manufacturing business models. J. Manuf. Technol. Manag. 2019, 30, 554-560. [CrossRef]

11. Takata, S.; Suemasu, K.; Asai, K. Life cycle simulation system as an evaluation platform for circular manufacturing systems. CIRP Ann. Manuf. Technol. 2019, 68, 21-24. [CrossRef]

12. Franco, M. Circular economy at the micro level: A dynamic view of incumbents' struggles and challenges in the textile industry. J. Clean. Prod. 2017, 168, 833-845. [CrossRef]

13. Landrum, N.; Ohsowski, B. Identifying worldviews on corporate sustainability: A content analysis of corporate sustainability reports. Bus. Strat. Environ. 2018, 27, 128-151. [CrossRef]

14. Geissdoerfer, M.; Savaget, P.; Bocken, N.; Hultink, E. The circular economy-A new sustainability paradigm? J. Clean. Prod. 2017, 143, 757-768. [CrossRef]

15. Elkington, J. Cannibals with Forks: The Triple Bottom Line of 21st Century Business; Capstone: Oxford, UK, 1997.

16. Ayres, R.U. Sustainability economics: Where do we stand? Ecological Economics. Ecol. Econ. 2008, 67, 281-310. [CrossRef]

17. Gardner, L.; Colwill, J. A framework and decision support tool for improving value chain resilience to critical materials in manufacturing. Prod. Manuf. Res. 2018, 6, 126-148. [CrossRef]

18. Šerešová, M.; Kočí, V. Proposal of package-to-product indicator for carbon footprint assessment with focus on the Czech Republic. Sustainability 2020, 12, 3034. [CrossRef]

19. Merli, R.; Preziosi, M.; Acampora, A. How do scholars approach the circular economy? A systematic literature review. J. Clean. Prod. 2018, 178, 703-722.

20. Manninen, K.; Koskela, S.; Antikainen, R.; Dahlbo, H. Do business models capture the circular economy value propositions? J. Clean. Prod. 2017, 171, 413-422. [CrossRef]

21. Stewart, R.; Niero, M. Circular economy in corporate sustainability strategies: A review of corporate sustainability reports in the fast-moving consumer goods sector. Bus. Strat. Environ. 2018, 27, 1005-1022. [CrossRef]

22. Angioletti, C.; Despeisse, M.; Rocca, R. Product circularity assessment methodology. In Advances in Production Management Systems. The Path to Intelligent, Collaborative and Sustainable Manufacturing; Lödding, H., Riedel, R., Thoben, K.D., von Cieminski, G., Kiritsis, D., Eds.; Springer: Cham, Switzerland; Berlin, Germany, 2017; pp. 411-418.

23. Moreno, M.; De los Rios, C.; Rowe, Z.; Charnley, F. A conceptual framework for circular design. Sustainability 2016, 8, 937. [CrossRef]

24. Masi, D.; Kumar, V.; Garza-Reyes, J.; Godsell, J. Towards a more circular economy: Exploring the awareness, practices, and barriers from a focal firm perspective. Prod. Plan. Control 2018, 29, 539-550. [CrossRef]

25. Whiteman, G.; Cooper, W. Ecological Embeddedness. Acad. Manag. J. 2000, 43, 1265-1282.

26. Hassan, M.; Nordin, N.; Ashari, H. Environmental stewardship issue among Malaysian manufacturing firms. Int. J. Supply Chain Manag. 2016, 5, 36-42.

27. Bennett, N.; Whitty, T.; Finkbeiner, E.; Pittman, J.; Bassett, H.; Gelcich, S.; Allison, E. Environmental stewardship: A conceptual review and analytical framework. Environ. Manag. 2018, 61, 597-614. [CrossRef] [PubMed]

28. Mathevet, R.; Bousquet, F.; Larrère, C.; Larrère, R. Environmental stewardship and ecological solidarity: Rethinking social-ecological interdependency and responsibility. J. Agric. Environ. Ethics 2018, 31, 605-623. [CrossRef]

29. Morris, C.; Kirwan, J. Ecological embeddedness: An interrogation and refinement of the concept within the context of alternative food networks in the UK. J. Rural Stud. 2011, 27, 322-330. [CrossRef]

30. Baritaux, V.; Houdart, M.; Boutonnet, J.P.; Chazoule, C.; Corniaux, C.; Fleury, P.; Lacombe, N.; Napoléone, M.; Tourrand, J.F. Ecological embeddedness in animal food systems (re-)localisation: A comparative analysis of initiatives in France, Morocco and Senegal. J. Rural Stud. 2016, 43, 13-26. [CrossRef]

31. Rahimifard, S.; Woolley, E.; Webb, P.; Garcia-Garcia, G.; Stone, J.; Jellil, A.; Gimenez-Escalante, P.; Jagtap, S.; Trollman, H. Forging new frontiers in sustainable food manufacturing. In Sustainable Design and Manufacturing; Springer: Cham, Switzerland; Berlin, Germany, 2017; pp. 13-24. 
32. Trollman, H.; Trollman, F. A sustainability assessment of smart innovations for mass production, mass customisation and direct digital manufacturing. In Mass Production Processes; Akdogan, A., Vanli, A.S., Eds.; InTechOpen: London, UK, 2019. [CrossRef]

33. Trollman, H. A novel approach to assessing manufacturer progress toward sustainability. Procedia CIRP 2018, 78, 370-375. [CrossRef]

34. Lumsakul, P.; Sheldrick, L.; Rahimifard, S. The sustainable co-design of products and production systems. Procedia Manuf. 2018, 21, 854-861. [CrossRef]

35. Bastianutti, J.; Dumez, H. Environmental sustainability for industry legitimacy and competitiveness. The case of CSR collective strategies in the cement industry. In Business Strategies for Sustainability; Borland, H., Lindgreen, A., Maon, F., Vanhamme, J., Ambrosini, V., Florencio, B., Eds.; Routledge: Abingdon, UK, 2019; pp. 65-80.

36. Hu, B.; Zhang, T.; Yan, S. How corporate social responsibility influences business model innovation: The mediating role of organizational legitimacy. Sustainability 2020, 12, 2667. [CrossRef]

37. Suchman, M.C. Managing legitimacy: Strategic and institutional approaches. Acad. Manag. Rev. 1995, 20, 571-610. [CrossRef]

38. Yin, R.K. Case Study Research, Design and Methods; Sage Publications: Thousand Oaks, CA, USA; New Delhi, India, 2003.

39. Zucchella, A.; Urban, S. Futures of the sustainable firm: An evolutionary perspective. Futures 2014, 63, 86-100. [CrossRef]

40. Creswell, J.W. Qualitative Inquiry \& Research Design Choosing Among Five Approaches; Sage: Thousand Oaks, CA, USA, 2013.

41. Halkier, B. Methodological practicalities in analytical generalization. Qual. Inq. 2011, 17, 787-797. [CrossRef]

42. Kosmützky, A.; Nokkala, T.; Diogo, S. Between context and comparability: Exploring new solutions for a familiar methodological challenge in qualitative comparative research. High. Educ. Q. 2020, 74, 176-192. [CrossRef]

43. British Standards: BS 8001: 2017 Circular Economy. 2017. Available online: https://www.bsigroup.com/ en-GB/standards/benefits-of-using-standards/becoming-more-sustainable-with-standards/BS8001-CircularEconomy/ (accessed on 18 December 2019).

44. Lindblom, C. Politics and Markets: The World's Political-Economic Systems; Basic Books: New York, NY, USA, 1977.

45. Press, M.; Robert, I.; Maillefert, M. The role of linked legitimacy in sustainable business model development. Ind. Mark. Manag 2019, in press, corrected proof. [CrossRef]

46. Tallberg, J.; Zürn, M. The legitimacy and legitimation of international organizations: Introduction and framework. Rev. Int. Organ. 2019, 14, 581-606. [CrossRef]

47. Bowman, M.; Marriott, R.; Woroniecka, K.; Taylor, J. Too Much of a Bad Thing: The Use and Misuse of UK Soil and Land to Grow Sugar; Feedback: London, UK, 2019.

48. Dowling, J.; Pfeffer, J. Organizational legitimacy: Social values and organizational behavior. Pac. Sociol. Rev. 1975, 18, 122-136. [CrossRef]

(C) 2020 by the authors. Licensee MDPI, Basel, Switzerland. This article is an open access article distributed under the terms and conditions of the Creative Commons Attribution (CC BY) license (http://creativecommons.org/licenses/by/4.0/). 